\title{
Kemampuan Literasi Matematika Siswa Berdasarkan Gender
}

\author{
Isnaniah $^{1 *}$, Charles ${ }^{2}$, M. Imamuddin ${ }^{3}$, Syahrul $^{4}$, Zulmuqim $^{5}$ \\ 1,234Institut Agama Islam Negeri (IAIN) Bukittinggi, Bukittinggi, Indonesia \\ ${ }^{5}$ Universitas Islam Negeri (UIN) Imam Bonjol Padang, Padang, Indonesia
}

${ }^{*}$ Corresponding Author

\begin{tabular}{l} 
Informasi Artikel \\
\hline Diterima Redaksi: 10 Juni 2021 \\
Revisi Akhir: 10 November 2021 \\
Diterbitkan Online: 31 Desember 2021 \\
Kata Kunci \\
\hline Kemampuan \\
Literasi Matematika \\
Gender \\
Korespondensi \\
\hline iis_imam@yahoo.co.id
\end{tabular}

\section{A B S T R A C T}

Literacy is an ability that must be possessed by every individual (student). Literacy plays an important role for students. One of the literacy that must be mastered by students is mathematical literacy. Regarding mathematical literacy, many previous researchers have conducted research and even recent research related to this literacy ability is associated with gender. This study aims to map and describe students' literacy skills and differentiate students' literacy skills based on gender. This research is a literature study research by referring to eight article documents. The article documents used as sources were taken randomly from the internet. The results of the analysis of this article document are as follows: 1. Research related to literacy and gender is mostly carried out at the high school level than at the junior high school level, 2. The indicators used in assessing students' literacy abilities are indicators modified from indicators used by the Quasar General Rubric , indicators used by PISA and indicators referring to problem solving steps, and 3. male students' mathematical literacy skills are better than female students' mathematical literacy skills.

Literasi merupakan kemampuan yang harus dimiliki oleh setiap individu (siswa). Literasi memegang peranan penting bagi siswa. Salah satu literasi yang harus dikuasai oleh siswa adalah literasi matematika. Terkait literasi matematika, sudah banyak peneliti terdahulu melakukan penelitian bahkan penelitian terkini terkait kemampuan literasi ini dikaitkan dengan gender. Penelitian ini bertujuan untuk memetakan dan mendeskripsikan kemampuan literasi siswa dan membedakan kemampuan literasi siswa berdasarkan gender. Penelitian ini adalah penelitian studi literatur dengan merujuk kepada delapan dokumen artikel Dokumen-dokumen artikel yang digunakan sebagai sumber diambil secara acak dari internet. Hasil dari analisis terhadap dokumen artikel ini adalah sebagai berikut: 1. Penelitian terkait literasi dan gender lebih banyak dilakukan di tingkat SMA daripada tingkat SMP, 2. Indikator yang digunakan dalam menilai kemampuan literasi siswa yaitu indikator yang dimodifikasi dari indikator yang digunakan oleh Quasar General Rubric, indikator yang digunakan PISA dan indikator yang mengacu pada langkah-langkah penyelesaian masalah, dan 3. kemampuan literasi matematika siswa laki-laki lebih baik daripada kemampuan litetarasi matematika siswa perempuan.

02021 by the authors. Submitted for possible open access publication under the terms and conditions of the

Creative Commons Attribution-ShareAlike 4.0 International License-(CC-BY-SA)

(https://creativecommons.org/licenses/by-sa/4.0/)

\section{Pendahuluan}

Literasi dalam KBBI didefinisikan sebagai kemampuan untuk melihat dan memahami isi dari apa yang tertulis (dengan melisankan atau hanya dalam hati), mengeja atau melafalkan apa yang tertulis, mengucapkan, mengetahui, meramalkan, menduga, dan memperhitungkan [25]. Literasi dipahami sebagai seperangkat kemampuan yang dimiliki individu dalam mengolah informasi, memahami dan menggunakan bahan-bahan bacaan sebagai sumber ilmu. Orang yang telah menguasai keterampilan membaca dan menulis dalam suatu bahasa disebut literat, sedangkan seseorang dianggap buta huruf (illiterate) jika dia tidak mampu membaca dan menulis. Dalam perkembangannya literasi tidak hanya "melek" huruf, secara istilah literasi mencangkup semua kemampuan yang berkaitan dengan bacaan dan wacana, [5]. Koichiro Matsura mengatakan, literasi juga mencakup bagaimana individu berkomunikasi dengan lingkungan sekitarnya yaitu masyarakat, [24]. Sejalan dengan itu, [22] mendefinisikan literasi sebagai kemampuan mengakses, memahami, dan menggunakan sesuatu secara cerdas melalui berbagai aktivitas, antara lain membaca, melihat, menyimak, menulis, dan/atau berbicara. Sedangkan [18] 
mengartikan literasi tidak hanya sekedar kemampuan individu dalam membaca dan berkomunikasi, tetapi literasi merupakan kemampuan individu untuk membaca, menulis, berbicara, menghitung dan memecahkan masalah pada tingkat keahlian yang diperlukan dalam pekerjaan, keluarga dan masyarakat.

Dari pengertian literasi di atas, dapat disimpulkan bahwa literasi adalah suatu aktiviitas yang di dalamnya menuntut berbagai macam kegiatan seperti membaca, berbicara, menulis, menghitung, menggambar, memahami, berfikir, menganalisis dan memecahkan masalah yang dihadapi dalam kehidupan sehari-harinya. Dengan kemampuan literasi yang dimilikinya, mampu membuat individu (siswa) menjadi individu yang bisa menyelesaikan masalah pribadi dan orang laiin yang ada disekitarnya.

Melihat pentingnya kemampuan literasi, maka siswa-siswa Indonesia harus memiliki kemampuan ini. Kemampuan literasi yang harus dimiliki oleh siswa Indonesia, salah satunya adalah kemampuan literasi matematika. Literasi matematika adalah segala kemampuan dalam memahami masalah, merencanakan, menganalisis dan menggunakan dalam kehidupan seharihari individu. Literasi matematika sebagai keterampilan dan pengetahuan yang dibutuhkan tidak hanya untuk dapat sekedar hidup dari segi finansial, tetapi sebagai suatu yang dibutuhkan untuk mengembangkan diri secara sosial, ekonomi, dan budaya dalam kehidupan modern, [17].

Begitu pentingnya kemampuan literasi matematika harus dimiliki oleh siswa-siswa Indonesia, maka sudah banyak para pemerhati pendidikan, peneliti, dosen atau guru-guru dan mahasiswa melakukan penelitian terkait kemampuan literasi matematika siswa. Bahkan pada akhir-akhir ini, kemampuan literasi juga dikaitkan dengan jenis kelamin dan gender. Jenis kelamin seperti laki-laki dan perempuan, dimana laki-laki ataupun perempuan ini mempunyai hak yang sama dalam belajar, apa lagi perempuan yang merupakan pendidik dalam keluarga khususnya pendidik bagi anaak-anaknya, [14].Gender adalah sifat yang dikenakan kepada individu yang disematkan oleh masyarakat dan lingkungannya.

Terkait matematika dan gender sudah banyak para peneliti terdahulu yang telah memulai melakukan penelitian, misalnya terkait penyelesaian masalah, komunikasi, kemampuan spasial ([8], [13], [9], [21]). Begitu banyaknya penelitian yang mengaitkan kemampuan matematika dengan gender ini, menarik penulis untuk melakukan penelitian terkait literasi matematika dan gender.

\section{Metode Penelitian}

Penelitian ini adalah penelitian studi literatur. Penelitian ini bertujuan untuk memetakan, memaparkan atau mendeskripsikan dan menyimpulkan perbedaan kemampuan literasi siswa berdasarkan gender. Dalam penelitian ini, perbedaan dan kemampuan literasi matematika siswa didasarkan dari penelitian-penelitian yang sudah diterbitkan yang berupa dokumen artikel yang sudah dilakukan oleh peneliti terdahulu. Untuk itu, peneliti melakukan studi literatur terhadap beberapa artikel yang diperoleh dari internet. Artikel dipilih secara acak, dan diperoleh delapan artikel yang terdiri dari dua artikel dari prosiding dan enam artikel dari jurnal OJS. Dua artikel dari prosiding yaitu: artikel yang ditulis oleh Florentina, dkk 2018 pada Prosiding Seminar Nasional Etnomatnesia ISBN: 978-602-6258-07-6, dan artikel yang ditulis oleh Suryaprani, dkk 2016 pada Prosiding Seminar Nasional MIPA 2016, FMIPA Undiksha ISBN 978-602-6428-00-4. Sedangkan enam artikel dari jurnal antara lain artikel yang ditulis oleh: Setiawan, dkk 2019 pada Jurnal Karya Pendidikan Matematika Vol 6 No 1 2019, Mahiuddin, dkk 2019 pada Jurnal Pendidikan Matematika Vol. 10, No. 1, 2019, 55-65, Nurani, dkk 2020 pada Jurnal Pendidikan Matematika Vol. 8, No. 4, pp. 336 - 347, Karmila 2028 pada Jurnal Pedagogy Volume 3 Nomor 1, Julisra dan Sepriyanti 2016 pada Math Educa Journal 3 (2) (2019): 195-206 dan Risywandha dan 
Khabibah pada jurnal MATHEdunesa Jurnal Ilmiah Pendidikan Matematika Volume 2 No.7 Tahun 2018. Analisis dilakukan dengan menganalisis dari hasil-hasil penelitian dari dokumendokumen artikel tersebut. Hasil analisis dikelompokkan menjadi tiga sub judul yaitu: tempat penelitian, indikator penilaian kemampuan literasi matematika, dan hasil penelitian.

\section{Hasil dan Pembahasan}

Dari hasil studi literatur terhadap beberapa dokumen artikel yang diambil secara acak dari internet diperoleh delapan dokumen artikel. Delapan dokumen artikel tersebut dituangkan dalam tabel 1 berikut.

Tabel 1. Artikel-artikel yang Dijadikan Bahan Penelitian

\begin{tabular}{|c|c|c|c|}
\hline No & Peneliti & Judul & Prosiding/Jurnal \\
\hline 1 & $\begin{array}{l}\text { Florentina, } \\
\text { dkk, } 2018\end{array}$ & $\begin{array}{l}\text { Analisis Kemampuan Lit- } \\
\text { erasi Matematika Kelas } \\
\text { VIII Menurut Gender }\end{array}$ & $\begin{array}{l}\text { Prosiding Seminar Na- } \\
\text { sional Etnomatnesia } \\
\text { ISBN: 978-602-6258-07-6 }\end{array}$ \\
\hline 2 & $\begin{array}{l}\text { Setiawan, } \\
\text { dkk, } 2019\end{array}$ & $\begin{array}{l}\text { Analisis Kemampuan Lit- } \\
\text { erasi Matematis Siswa } \\
\text { Dalam } \\
\text { Penyelesaian Soal Pisa } \\
\text { Ditinjau Dari Gender }\end{array}$ & $\begin{array}{l}\text { Jurnal Karya Pendidikan } \\
\text { Matematika Vol } 6 \text { No } 1 \\
2019\end{array}$ \\
\hline 3 & $\begin{array}{l}\text { Suryaprani, } \\
\text { dkk, } 2016\end{array}$ & $\begin{array}{l}\text { Hubungan Jenis Kelamin, } \\
\text { Literasi matematika, Dan } \\
\text { Disposisi Matematika Ter- } \\
\text { hadap Prestasi Belajar } \\
\text { Matematika Peserta Didik } \\
\text { SMA Negeri Di Denpasar }\end{array}$ & $\begin{array}{l}\text { Prosiding Seminar Na- } \\
\text { sional MIPA 2016, FMIPA } \\
\text { Undiksha } \\
\text { ISBN 978-602-6428-00-4 }\end{array}$ \\
\hline 4 & $\begin{array}{l}\text { Mahiuddin, } \\
\text { dkk, } 2019 .\end{array}$ & $\begin{array}{l}\text { Analisis Kemampuan Lit- } \\
\text { erasi Matematis Siswa } \\
\text { SMP Di Kabupaten } \\
\text { Konawe Dalam Perspektif } \\
\text { Gender }\end{array}$ & $\begin{array}{l}\text { Jurnal Pendidikan Ma- } \\
\text { tematika } \\
\text { Vol. } 10 \text {, No. 1, 2019, 55-65 }\end{array}$ \\
\hline 5 & $\begin{array}{l}\text { Nurani dkk, } \\
2020 .\end{array}$ & $\begin{array}{l}\text { Analisis Kemampuan Lit- } \\
\text { erasi Matematika Siswa } \\
\text { SMA Ditinjau dari Gender }\end{array}$ & $\begin{array}{l}\text { Jurnal Pendidikan Ma- } \\
\text { tematika } \\
\text { Vol. } 8 \text {, No. } 4 \text {, pp. } 336-347\end{array}$ \\
\hline 6 & $\begin{array}{l}\text { Karmila, } \\
2018 .\end{array}$ & $\begin{array}{l}\text { Deskripsi Kemampuan } \\
\text { Literasi Matematis Siswa } \\
\text { Ditinjau Dari Gender }\end{array}$ & $\begin{array}{l}\text { Pedagogy } \\
\text { Volume } 3 \text { Nomor } 1\end{array}$ \\
\hline 7 & $\begin{array}{l}\text { Julisra dan } \\
\text { Sepriyanti, } \\
2019\end{array}$ & $\begin{array}{l}\text { Kemampuan Literasi Ma- } \\
\text { tematis Peserta Didik Da- } \\
\text { lam Perspektif } \\
\text { Gender Di Kelas X Mia } 7 \\
\text { SMAN } 10 \text { Padang }\end{array}$ & $\begin{array}{l}\text { Math Educa Journal } 3 \text { (2) } \\
\text { (2019): 195-206 }\end{array}$ \\
\hline 8 & $\begin{array}{l}\text { Risywandha } \\
\text { dan } \\
\text { Khabibah, } \\
2018 .\end{array}$ & $\begin{array}{l}\text { Literasi Matematika Siswa } \\
\text { Sma Kelas X Dalam Me- } \\
\text { nyelesaikan Soal Model } \\
\text { Pisa Ditinjau Dari Perbe- } \\
\text { daan Gender }\end{array}$ & $\begin{array}{l}\text { MATHEdunesa Jurnal } \\
\text { Ilmiah Pendidikan Ma- } \\
\text { tematika Volume } 2 \text { No. } 7 \\
\text { Tahun } 2018\end{array}$ \\
\hline
\end{tabular}

Berdasarkan studi literatur kepada dokumen-dokumen artikel ini, diperoleh informasi terkait jenjang penelitian atau tempat dilakukan penelitian, indikator penelitian yang digunakan 
dalam melakukan penilaian kemampuan literasi siswa dan hasil penelitian dari masing-masing penelitian. Adapun penjelasan dari masing-masing informasi dideskripsikan sebagai berikut:

\subsection{Tempat Penelitian}

Berdasarkan dokumen-dokumen yang dijadikan sebagai subjek penelitian, penelitian dilaksanakan di SMP dan SMA. Adapun persentase tempat penelitian dapat dilihat pada gambar 1 berikut ini.

\section{Tingkat Sekolah}

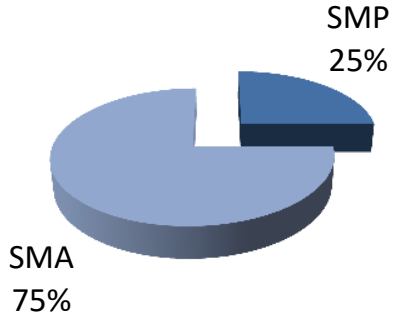

Gambar 1. Persentase Tempat Penelitian

Dari gambar 1. di atas, persentase tempat melaksanakan penelitian terkait literasi matematika siswa dan gender yaitu $25 \%$ melaksanakan penelitian atau melakukan penelitian terhadap siswa SMP dan 75\% melakukan atau melaksanakan penelitian pada siswa SMA.

\subsection{Indikator Penilaian Kemampuan Literasi Matematika}

Dari dokumen-dokumen artikel yang telah dianalisis diperoleh indikator penilaian kemampuan literasi matematika siswa yang digunakan dalam penelitian-penelitian itu antara lain: (a) Indikator kemampuan literasi dari Quasar General Rubric (Lane, 1993) yang sudah dilakukan dimodifikasi sesuai dengan kebutuhan penelitian sipeneliti, (b) Indikator literasi matematika yang digunakan oleh PISA, dan (c) Indikator penelitian terkait literasi yang berdasarkan kepada langkah-langkah penyelesaian masalah.

\subsection{Hasil Penelitian}

Sedangkan hasil analisis terhadap dokumen artikel terkait hasil penelitian adalah sebagai berikut: (a). Menyimpulkan laki-laki lebih baik dalam literasi matematika anatara lain hasil penelitian dari: tingkat kemampuan literasi matematika siswa laki-laki lebih tinggi dibandingkan dengan siswa perempuan [4], kemampuan literasi matematis siswa laki-laki dapat dikatakan sudah baik, ([26], [23]), peserta didik laki-laki mendapatkan skor kemampuan literasi lebih besar dibandingkan dengan skor literasi matematis peserta didik perempuan, [15]. (b). Menyimpulkan Perempuan lebih baik daripada laki-laki dalam dari segi kemampuan literasi matematika antara lain: kemampuan literasi siswa perempuan lebih baik dari pada siswa laki-laki, [19] dan perempuan (feminine) lebih memunculkan semua indikator daripada laki-laki (maskulin), [7], dan (c). Kemampuan literasi matematika siswa laki-laki dan perempuan setara: kemampuan literasi matematis siswa laki-laki setara dengan kemampuan literasi matematis siswa perempuan, [16], kemampuan literasi matematika siswa laki-laki dan perempuan sama-sama lemah. 
Untuk lebih jelasnya persentase dari hasil studi literatur terkait kemampuan literasi berdasarkan gender ini, maka disajikan dalam dalam Gambar 2. berikut.

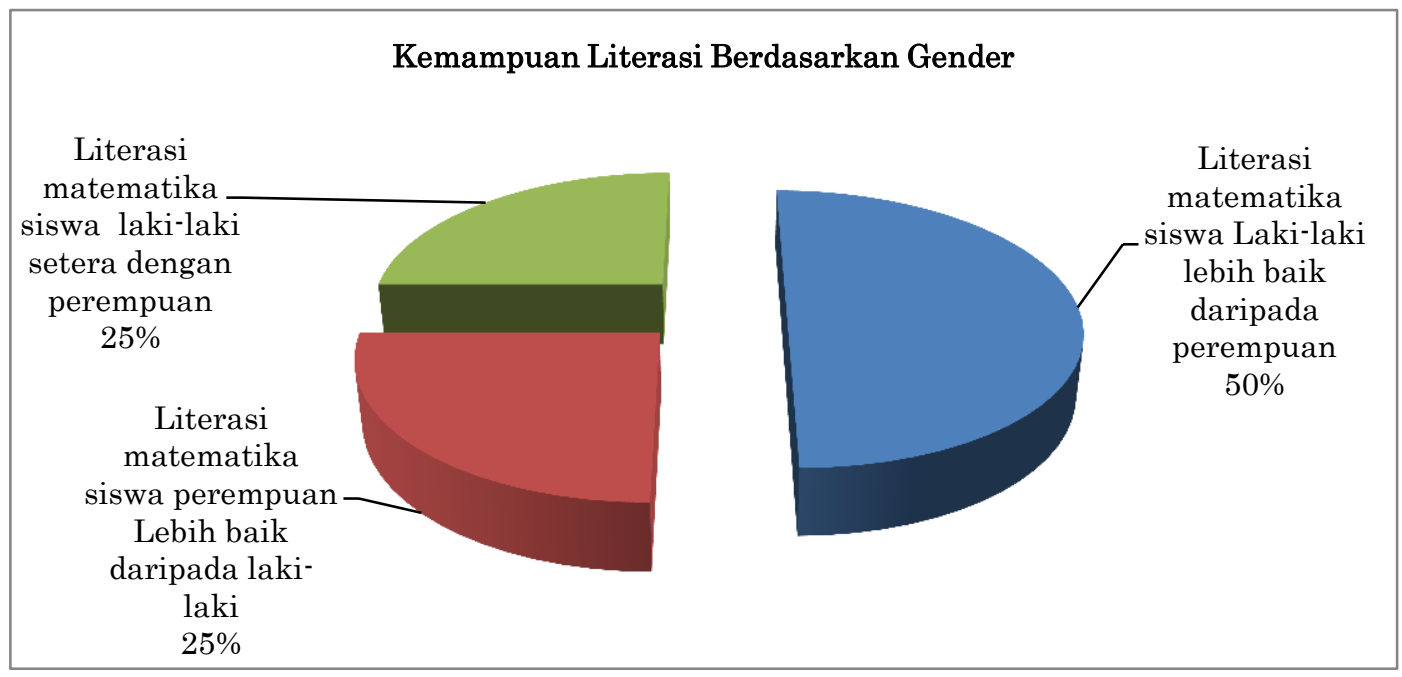

Gambar 3. PersentaseKemampuan Literasi Laki-laki dan Perempuan

Berdasarkan Gambar 3 ini, sebanyak 50\% dari hasil penelitian menyimpulkan kemampuan literasi matematika siswa laki-laki lebih baik daripada siswa perempuan, 25\% hasil penelitian menyimpulkan kemampuan literasi matematika siswa perempuan lebih baik daripada siswa laki-laki, dan yang terahir $25 \%$ hasil penelitian menyimpulkan kemampuan literasi matematika siswa laki-laki setara dengan kemampuan literasi matematika siswa perempuan. Berdasarkan studi literatur ini, maka dapat dikatakan bahwa kemampuan literasi matematika siswa laki-laki lebih baik daripada kemampuan literasi matematika siswa perempuan, [4], [26], [23], [15], Selain itu, berdasarkan penelitian-penelitian matematika terdahulu, kajian-kajian matematika dan berdasarkan karakteristik dari matematika sendiri yang terdiri dari konsep [14], fakta, prinsip dan kompleksitas dari matematika. Dari kekomplekan matematika ini, sudah banyak hasil-hasil penelitian terdahulu yang menyimpulkan/menyatakan kemampuan siswa laki-laki lebih baik daripada kemampuan siswa perempuan ([2], [12], [13], Selain itu konten-konten dari matematika seperti geometri, aljabar, numeric, diskrit dan lain-lain juga sangat berpengaruh terhadap penguasaan matematika siswa terkusus dari segi gender.

\section{Kesimpulan}

Berdasarkan penelitian yang telah dilakukan terhadap delapan artikel ini, maka dapat disimpulkan bahwa: (a) penelitian terkait literasi dan gender lebih banyak dilakukan di tingkat SMA daripada tingkat SMP, (b) Indikator yang digunakan dalam menilai kemampuan literasi siswa yaitu indikator yang dimodifikasi dari indikator yang digunakan oleh Quasar General Rubric, indikator yang digunakan PISA dan indikator yang mengacu pada langkah-langkah pemnyelesaian masalah, dan (3), kemampuan literasi matematika siswa laki-laki lebih baik daripada kemampuan lietarasi matematika siswa perempuan.

Saran bagi peneliti berikutnya yang akan melakukan penelitian serupa dengan ini, agar melakukan penelitian yang lebih besar dari segi jumlah dokumen dengan rentang waktu yang panjang. Banyaknya dokumen artikel sebagai sumber kajian dalam penelitian akan mampu menghasilkan penelitian yang lebih baik terkait literasi matematika dan gender sehingga hasil yang diperoleh lebih mewakili untuk dijadikan dasar dalam mengambil keputusan. 


\section{Daftar Pustaka}

[1] De Lang, Jane, 2007. Mathematics for Literacy, dalam Quantitative Literacy, Why Numeracy Matters for schools and Colleges, Proceding of the National Foum on Quantitative Litera$c y$. Washington D.C.: National Academy of Sciences.

[2] Firmanti, Pipit, 2018. Penalaran Siswa Laki-laki dan Perempuan dalam Proses Pembelajaran Matematika, HUMANISMA: Journal of Gender Studies 1 (2), 73-85, 2018.

[3] Fitri, H. Aniswita dan Charles, 2019. Factors of Affecting Thesis Completion by Using Chaid Method Based on Gender, HUMANISMA: Journal of Gender Studies 3 (1), 27-41, 2019.

[4] Florentina,O.L., Maharani R.M., \& Pratiwi, H.S., 2018. Analisis Kemampuan Literasi Matematika Kelas VIII Menurut Gender, Prosiding Seminar Nasional Etnomatnesia ISBN: 978-602-6258-07-6.

[5] Gong, Gol A. dan Irkham, Agus M., 2012. Gempa Literasi dari Kampung untuk Nusantara, Jakarta: Kepustakaan popular Gramedia.

[6] I Izmuddin, P Harahap, W Syafitri, dan M Imamuddin, 2021. Digital Based Education Through Econophysical Modeling, Journal of Physics: Conference Series 1779 (1), 012032 , 2021.

[7] Ihmah Risywandha dan Siti Khabibah, 2018. Literasi Matematika Siswa Sma Kelas X Dalam Menyelesaikan Soal Model Pisa Ditinjau Dari Perbedaan Gender, MATHEdunesa Jurnal Ilmiah Pendidikan Matematika 2 (7), 2018.

[8] Imamuddin, M., dan Isnaniah, 2018. Profil Kemampuan Spasial Mahasiswa Camper dalam Merekonstruksi Irisan Prisma Ditinjau dari Perbedaan Gender, MaPan: Jurnal Matematika dan Pembelajaran 6 (1), 31-39, 2018, DOI: https://doi.org/10.24252/mapan.2018v6n1a4

[9] Imamuddin, M., Isnaniah I., Rusdi R., Pedinal P., 2019, Gender Based Perseption on Understanding Mathematics Consept by Using PBL, HUMANISMA: Journal of Gender Studies 3 (1), 58-74, 2019,DOI: http://dx.doi.org/10.30983/humanisme.v3i1.1061.

[10] Imamuddin, M., Andryadi Andryadi, M. Zaharuddin, Isnaniah Isnaniah, Weti Susanti, Rehani Rehani, Zulmuqim Zulmuqim \& Syafruddin Nurdin, 2020. The Role of Women as Educators, NUR EL-ISLAM, Jurnal Pendidikan dan Sosial Keagamaan 7(2), 138-157, 2020, DOI: https://doi.org/10.51311/nuris.v7i2.190.

[11] Imamuddin, M. dan Isnaniah, 2018, Kemampuan Spasial Mahasiswa Calon Guru Matematika Berjenis Kelamin Perempuan dalam Merekonstruksi Irisan Prisma, Math Educa Journal 2 (1), 72-78, 2018, DOI: https://doi.org/10.15548/mej.v2i1.177.

[12] Imamuddin, M. 2018, Kemampuan Spasial Mahasiswa Laki-Laki dan Perempuan Dalam Menyelesaikan Masalah Geometri, HUMANISMA: Journal of Gender Studies 1 (2), 38-47, 2018, DOI: http://dx.doi.org/10.30983/jh.v1i2.223.

[13] Isnaniah, 2018, Komunikasi Matematis Dalam Pembelajaran Berdasarkan Gender, $H U$ MANISMA: Journal of Gender Studies 1 (2), 13-23, 2018, । DOI: http://dx.doi.org/10.30983/jh.v1i2.254.

[14] Isnaniah dan Imamuddin, M., 2020. Students' Understanding of Mathematical Concepts Using Manipulative Learning Media in Elementary Schools J. Phys. Conf. Ser. 1471.

[15] Julisra W., dan Sepriyanti N., 2019. Kemampuan Literasi Matematis Peserta Didik Dalam Perspektif Gender Di Kelas X Mia 7 SMAN 10 Padang, Math Educa Journal 3 (2) (2019): 195-206, 2019.

[16] Karmila, 2018. Deskripsi Kemampuan Literasi Matematis Siswa Ditinjau Dari Gender, Pedagogy 3 (1), 126-155, 2018. 
[17] Kusumah, Yaya S., Literasi Matematis. Prosiding Seminar Nasional Pendidikan MIPA. Pengembangan Pembelajaran MIPA Berorientasi Soft Skill Universitas. Bandar Lampung, 26 November 2011. PMIPA FKIP Universitas Lampung (U-1).

[18] Majid, Abdul 2012. Belajar dan Pembelajaran: Pendidikan Agama Islam, Bandung: PT Remaja Rosdakarya.

[19] Nurani M., Mahfud M.S., Agustin R.L., \& Kananda K.V., 2020. Analisis Kemampuan Literasi Matematika Siswa SMA Ditinjau dari Gender, Jurnal Pendidikan Matematika 8 (4), $336-347,2020$.

[20] Ojose, Bobby. 2011. Mathematics Literacy: Are We Able to Put The Mathematics We Learn into Everyday Use? Journal of Mathematics Education, 4(1), 90, 2011.

[21] Rahmat T., 2019. Proses Berpikir Mahasiswa Program Studi Matematika IAIN Bukittinggi dalam memecahkan Masalah Geometri Ditinjau dari Perbedaan Gender, Jurnal Educative: Journal of Educational Studies 4 (1), 69-80, 2019.

[22] Retnaningdyah P., Laksono K., Mujiyem, Setyorini N.P., Sulastri, \& Hidayati U.S., 2016. Gerakan Literasi Sekolah di Sekolah Menengah Pertama, Jakarta: Direktorat Jenderal Pendidikan Dasar dan Menengah Kementerian Pendidikan dan Kebudayaan.

[23] Setiawan A., Inganah S., \& Ummah S.K., 2019. Analisis Kemampuan Literasi Matematis Siswa Dalam Penyelesaian Soal Pisa Ditinjau Dari Gender, Jurnal Karya Pendidikan Matematika 6 (1), 43-48, 2019.

[24] Solehudin, 2018. Keefektifan Program Literasi Alquran Di Sekolah-Sekolah Swasta NonAgama Dalam Kerangka Penguatan Karakter (Kajian Di Jawa Barat), Al-Bayan: Jurnal Studi Al-Qur"an dan Tafsir 3 (2), 168-188, Desember 2018.

[25] Suharso dan Retnoningsih, 2005. Kamus Besar Bahasa Indonesia, Semarang: CV. Widya Karya.

[26] Suryaprani M.W., Suparta I.N., \& Suharta I.G.P., 2016. Hubungan Jenis Kelamin, Literasi matematika, Dan Disposisi Matematika Terhadap Prestasi Belajar Matematika Peserta Didik SMA Negeri Di Denpasar, Prosiding Seminar Nasional MIPA 2016, FMIPA Undiksha ISBN 978-602-6428-00-4.

[27] Wahyu Pratama Mahiuddin, dkk 2019. Analisis Kemampuan Literasi Matematis Siswa SMP Di Kabupaten Konawe Dalam Perspektif Gender, Jurnal Pendidikan Matematika 10 (1), 55-65, 2019. 